\title{
Effects of cadmium chloride on mouse inner medullary collecting duct cells
}

\section{Eun-Kee PARK ${ }^{1}$, Sally K. MAK ${ }^{2}$, Bruce D. HAMMOCK ${ }^{3}$}

1 Department of Medical Humanities and Social Medicine, College of Medicine, Kosin University, Busan, Republic of Korea

2 Physiological Genomics Group, Department of Animal Science, University of California, Davis, CA, USA

${ }^{3}$ Department of Entomology and UCD Comprehensive Cancer Center, University of California, Davis, CA, USA

ITX060313C01 • Received:04 July 2013 • Revised: 10 August 2013 • Accepted: 17 August 2013

\section{ABSTRACT}

Cadmium is a known renal toxin. The cytotoxic effect of cadmium chloride $\left(\mathrm{CdCl}_{2}\right)$ was evaluated on renal inner medullary collecting duct cells (mIMCD3). The $24 \mathrm{hr} \mathrm{LC}_{50}$ value for $\mathrm{CdCl}_{2}$ in mIMCD3 cells was $40 \mu \mathrm{M}$. The present study showed that mIMCD3 cells were sensitive to $\mathrm{CdCl}_{2}$ exposure.

KEY WORDS: cadmium chloride; cytotoxicity; kidney; mIMCD3 cells

\section{Introduction}

Cadmium exposure is a public health concern for renal diseases, even at low levels of exposure (Ferraro et al., 2010; Kobayashi et al., 2009; Thomas et al., 2009) because the kidney is the organ most sensitive to cadmium toxicity (Järup et al., 1998). Most renal cell studies have focused less on the inner medulla although it is often exposed to high concentrations of common nephrotoxins (Burg, 2002; Rocha et al., 2001; Yancey et al., 1982). Renal inner medullary collecting duct cells (mIMCD3), which are an immortalized cell line derived from the mouse renal inner medulla, have proven a useful system to investigate effects of nephrotoxins (Cai et al., 2003; Kojima et al., 2011; Park et al., 2007; Park et al., 2008; Schenk et al., 2010). The present study investigated the effect of cadmium chloride on mIMCD3 cells.

\section{Materials and methods}

\section{Cell culture and chemicals}

This experiment was performed as previously described (Park et al., 2007; Park et al., 2008). All reagents for cell culture were purchased from Life Technologies (Carlsbad,

\footnotetext{
Correspondence address: Eun-Kee Park, PhD.

Department of Medical Humanities and Social Medicine, College of Medicine, Kosin University

262 Gamcheonro, Seogu, Busan 602-702, Republic of Korea.

TEL.: +82-51-990-5424 • FAX +82-51-241-5458

E-MAlL: ekpark@kosin.ac.kr
}

CA, USA). Briefly, mIMCD3 cells were grown in the presence of 45\% Ham's F-12, 45\% Dulbecco's modified Eagle's medium, $10 \%$ fetal bovine serum (FBS), 10 milliunits $/ \mathrm{ml}$ penicillin and $10 \mu \mathrm{g} / \mathrm{ml}$ streptomycin. The final osmolality of isosmotic medium was $300 \pm 5 \mathrm{mosmol} / \mathrm{kg}$ medium, which was confirmed by a microosmometer (Model 3300, Advanced Instruments, Norwood, MA, USA). Cells were grown at $37^{\circ} \mathrm{C}$ and $5 \% \mathrm{CO}_{2}$. Cadmium chloride $\left(\mathrm{CdCl}_{2}\right)$ was purchased from Sigma (St. Louis, MO, USA) and dissolved in Milli-Q water (Millipore, Bedford, MA, USA) freshly.

\section{Cytotoxicity assays}

Cell viability to determine the cytotoxic effect of $\mathrm{CdCl}_{2}$ was carried out using the 3-(4,5-dimethylthiazol-2-yl)2,5-diphenyl tetrazolium bromide (MTT) assay (Roche Applied Science, IN, USA) as described previously (Park et al., 2007; Park et al., 2008). Briefly, mIMCD3 cells were grown, trypsinized, and seeded evenly with $100 \mu \mathrm{L}$ of medium into each well of a flat-bottomed 96-well cell culture plate (Nalge-Nunc, Rochester, NY, USA). Once confluent, the desired concentrations of $\mathrm{CdCl}_{2}$ for testing were diluted from a stock solution, added to the wells and incubated in a humidified incubator of $5 \% \mathrm{CO}_{2}$ at $37^{\circ} \mathrm{C}$ for $24 \mathrm{hr}$. Controls were the cells without $\mathrm{CdCl}_{2}$ treatment. MTT assay was performed according to the manufacture's instruction. Briefly, $10 \mu \mathrm{L}$ MTT reagent was added into each well and cells incubated for $4 \mathrm{hr}$, followed by addition of $100 \mu \mathrm{L}$ of solubilization solution into each well. After $24 \mathrm{hr}$ incubation, the ratio of absorbance at $560 \mathrm{~nm}$ versus $750 \mathrm{~nm}$ was measured with a SpectraFluor Plus microplate reader (Tecan, Durham, NC, USA). This 


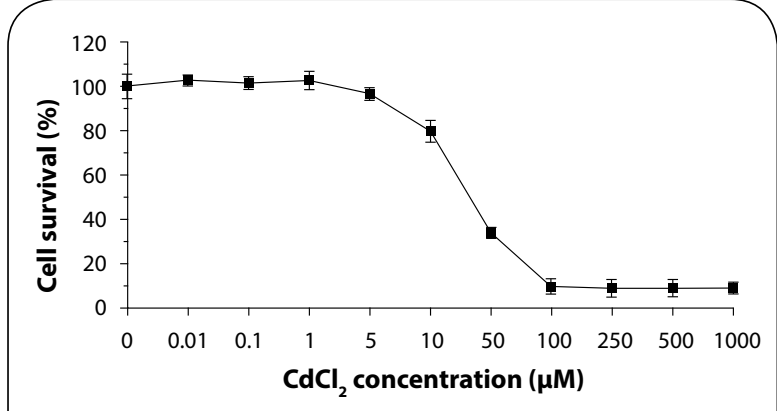

Figure 1. Cytotoxicity caused by $\mathrm{CdCl}_{2}$ in $\mathrm{mIMCD} 3$ cells in normal isosmotic (300 mosmol $/ \mathrm{kg}$ ) medium. Data are expressed as $\%$ cell survival compared to control (5 independent experiments).

ratio represented a measure of viable cells in each well and this ratio was normalized to controls that were run in parallel in the 96-well plate. Each condition was repeated in 8 wells and experiments were independently replicated 5 times. The concentration at which after $24 \mathrm{hr}$ half of the cells for each of concentration of the toxins tested were viable $\left(\mathrm{LC}_{50}\right)$ was determined. The results were expressed as percentage of cell survival compared to the control. Data were presented as mean \pm S.E.M.

\section{Results and discussion}

Control (water) had no influence on the survival of mIMCD3 cells. The $24 \mathrm{hr} \mathrm{LC}_{50}$ value for $\mathrm{CdCl}_{2}$ in mIMCD3 cells was $40 \mu \mathrm{M}$ in this experiment (Figure 1 ). The results of this study demonstrated that $\mathrm{CdCl}_{2}$ is directly toxic to mIMCD3 cells, which are well suited for this study. Previous studies reported that cadmium chloride $\left(\mathrm{CdCl}_{2}\right)$ caused damage to the proximal tubular epithelium of the mammalian kidney (Järup, 2002; Prozialeck et al., 1993; Van Vleet \& Schnellmann, 2003). A similar toxic effect of $\mathrm{CdCl}_{2}$ in LLC-PK1 cells (pig renal proximal tubule cell line) was found with a $24 \mathrm{hr} \mathrm{LC} \mathrm{L}_{50}$ value of $50 \mu \mathrm{M}$ (Gennari et al., 2003). The cell viability at $9 \mathrm{hr}$ was decreased by $38 \%$ and $45 \%$ at 25 and $50 \mu \mathrm{M} \mathrm{CdCl}_{2}$, respectively (Gena et al., 2010). $\mathrm{CdCl}_{2}$ was reported to cause DNA strand breaks, lipid peroxidation, reactive oxygen species, induction of necrosis and apoptosis, and to inhibit Na, K-ATPase (Kinne-Saffran et al., 1993; Mao et al., 2007; Mao et al., 2011; Valverde et al., 2001).

Overall, the present study revealed that cadmium chloride has a toxic effect on inner medulla areas and that mIMCD3 cells could be suited for studying the mechanisms related to $\mathrm{CdCl}_{2}$ toxicity.

\section{Acknowledgements}

The study was supported by grants from the National Institute of Environmental Health Sciences Superfund Basic Research Program P42 ES04699.
Author disclosure statement: No competing financial interest exists.

\section{REFERENCES}

Burg MB. (2002). Response of renal inner medullary epithelial cells to osmotic stress. Comp Biochem Physiol A Mol Integr Physiol 133: 661-666.

Cai Q, Dmitrieva NI, Michea LF, Rocha G, Ferguson D and Burg MB. (2003). Toxicity of acetaminophen, salicylic acid, and caffeine for first-passage rat renal inner medullary collecting duct cells. J Pharmacol Exp Ther 306: 3542.

Ferraro PM, Costanzi S, Naticchia A, Sturniolo A and Gambaro G. (2010). Low level exposure to cadmium increases the risk of chronic kidney disease: analysis of the NHANES 1999-2006. BMC Public Health 10: 304.

Gena P, Calamita G and Guggino WB. (2010). Cadmium impairs albumin reabsorption by down-regulating megalin and $\mathrm{CIC} 5$ channels in renal proximal tubule cells. Environ Health Perspect 118: 1551-1556.

Gennari A, Cortese E, Boveri M, Casado J and Prieto P. (2003). Sensitive endpoints for evaluating cadmium-induced acute toxicity in LLC-PK1 cells. Toxicol 183: 211-220.

Järup L. (2002). Cadmium overload and toxicity. Nephrol Dial Transplant 17(Suppl2): 35-39.

Järup L, Berglund M, Elinder CG, Nordberg G and Vahter M. (1998). Health effects of cadmium exposure - a review of the literature and a risk estimate. Scand J Work, Environ Health 24(Suppl 1): 1-51.

Kinne-Saffran E, Hülseweh M, Pfaff C and Kinne RK. (1993). Inhibition of Na,KATPase by cadmium: different mechanisms in different species. Toxicol Appl Pharmacol 121: 22-29.

Kobayashi E, Suwazono Y, Dochi M, Honda R and Kido T. (2009). Influence of consumption of cadmium-polluted rice or Jinzu river water on occurrence of renal tubular dysfunction and/or itai-itai disease. Bio Trace Elem Res 127: 257-268.

Kojima N, Saito H, Nishikawa M, Yuri S, Jo OD, Pham PC, Yanagawa N and Yanagawa N. (2011). Lithium induces c-Ret expression in mouse inner medullary collecting duct cells. Cell Signal 23: 371-379.

Mao WP, Ye JL, Guan ZB, Zhau JM, Zhang C, Zhang NN, Jiang P and Tian T. (2007). Cadmium induces apoptosis in human embryonic kidney (HEK) 293 cells by caspase-dependent and -independent pathways acting on mitochondria. Toxicol In Vitro 21: 343-354.

Mao WP, Zhang NN, Zhou FY, Li WX, Liu HY, Feng J, Zhou L, Wei CJ, Pan YB and $\mathrm{He} Z \mathrm{ZJ}$. (2011). Cadmium directly induced mitochondrial dysfunction of human embryonic kidney cells. Hum Exp Toxico/ 30: 920-929.

Park EK, Mak SK, Kultz D and Hammock BD. (2007). Evaluation of cytotoxicity attributed to thimerosal on murine and human kidney cells. J Toxicol Environ Health A 70: 2092-2095.

Park EK, Mak SK, Kultz D and Hammock BD. (2008). Determination of cytotoxicity of nephrotoxins on murine and human kidney cell lines. J Environ SCi Health B 43: 71-74.

Prozialeck WC, Wellington DR and Lamar PC. (1993). Comparison of the cytotoxicity effects of cadmium chloride and cadmium-metallothionein in LLCPK1 cells. Life Sci 53: 337-342.

Rocha GM, Michea LF, Peters EM, Kirby M, Xu Y, Ferguson DR and Burg MB. (2001). Direct toxicity of nonsteroidal antiinflammatory drugs for renal medullary cells. Proc Natl Acad Sci USA 98: 5317-5322.

Schenk LK, Rinschen MM, Klokkers J, Kurian SM, Neugebauer U, Salomon DR, Pavenstaedt H, Schlatter E and Edemir B. (2010). Cyclosporin-A induced toxicity in rat renal collecting duct cells: interference with enhanced hypertonicity induced apoptosis. Cell Physiol Biochem 26: 887-900.

Thomas LD, Hodgson S, Nieuwenhuijsen M and Jarup L. (2009). Early kidney damage in a population exposed to cadmium and other heavy metals. Environ Health Perspect 117: 181-184.

Van Vleet TR and Schnellmann RG. (2003). Toxic nephropathy: environmental chemicals. Semin Nephrol 23: 500-508.

Valverde M, Trejo C and Rojas E. (2001). Is the capacity of lead acetate and cadmium chloride to induce genotoxic damage due to direct DNA-metal interaction? Mutagenesis 16: 265-270.

Yancey PH, Clarl ME, Hand SC, Bowlus RD and Somero GN. (1982). Living with water stress: Evolution of osmolyte systems. Science 217: 1214-1222. 